\title{
脳動脈瘤破裂によるくも膜下出血急性期に 洞不全症候群を呈した 1 症例
}

\author{
山本 正昭 ${ }^{1)}$ 溝口 强美1) 篠原 弘一2) \\ 坂上 明彦2) 朝長 正道 ${ }^{3)}$
}

要旨：くも膜下出血急性期には高率に心電図異常が出現するといわれている. 我々も一過性 の洞不全症候群を呈した症例を経験した。症例は63歳女性, 前交通動脈瘤の破裂によるくも膜 下出血で, 神経学的には意識混濁の状態であった。 入院時の心電図は正常洞調律で, QTU 延長 がみられる以外には異常はなかったが, 発症 40 時間頃より心拍数 $40 / \mathrm{min}$ 以下の高度の徐脈が出 現し，3秒以上の洞停止と洞不整脈がみられた. Atropine に対して反応しないため，一時ぺー シングを行い，第 3 病日に開頭動脈瘤クリッピング術を行った。この症例では，検査所見より 弁膜疾患や心筋自体の器質的障害が否定され，また徐脈は急性期に一過性で消失しており，そ の後繰り返し行われた 24 時間ホルター心電図および電気生理学的検査の結果より刺激伝導系の 機能に異常はみられず, くも膜下出血にともなった中权性不整脈と診断した.

Key words : subarachnoid hemorrhage, sinus bradycardia, sick sinus syndrome, temporary cardiac pacing

（脳卒中13：400-404, 1991）

\section{はじめに}

くも膜下出血の急性期には心電図異常が出現しやす いことが知られて打り ${ }^{11216)}$, それは波形の異常と不整 脈に大別される。電図波形の異常として致死的不整 脈である torsade de pointes ( Tdp) 型の心室頻拍に つながる危険がある QTc 間隔の延長が最も特徵的な 所見であり 122)51 1012214)15)，つぎに不整脈は頻脈性心房 粗細動, 多源性頻発性心室性期外収縮, Tdp な゙の発 作性心室頻拍および心室細動などが malignant arrhythmia として注目されている(1) 4)6) -9913).

しかしながら,このような重症の不整脈は希であり， 散発性にみられる上室性㧍よび心室性期外収縮, 洞性 頻脈および洞性徐脈などが多いとされてい $3^{2(3) 667) 9116)}$. 特に徐脈性の不整脈はくも膜下出血の急 性期に多くみられるにも拘わらず133668)9916)，あまり関 心が払われていない.

我々は最近くも膜下出血急性期に一過性の洞不全症

1）白十字病院脳神経外科

2) 白十字病院循環器内科

3）福岡大学脳神経外科
候群を呈し，一時ペーシングを行った症例を経験した ので文献的考察を加えて報告する。

\section{症例}

[患者] 62歳, 女性.

〔主訴〕突然の頭痛, 意識障害.

〔既往歴〕数年前より高血圧症を指摘されていたが 放置していた。

〔現病歴〕平成 2 年11月 21 日, 突然の頭痛に引き続 き意識障害が出現し, 近医に搬入された. CTでくも膜 下出血と診断され，11月22日当院に入院した.

〔現症〕項部硬直, 軽度の意識混濁があり, Hunt \& Kosnik grade III であった。体温 $37.1^{\circ} \mathrm{C}$, 呼吸は整, 血圧は $134 / 70 \mathrm{mmHg}$ で, 脈拍は $66 / \mathrm{min}$ 不整はなかっ た.

〔検查所見〕血清電解質は $\mathrm{Na} 144 \mathrm{mEq} / l, \mathrm{~K} 3.6$ $\mathrm{mEq} / l$ と正常範囲内で, その他の血液生化学的検查で も異常はなかった。胸部 X 線撮影では CTR が $55 \%$ と 軽度の心拡大があった。入院時の心電図は正常洞調律 であったが，giant U 波拈よびQTU間隔の延長がみ られた (Fig. 1). 
aVR

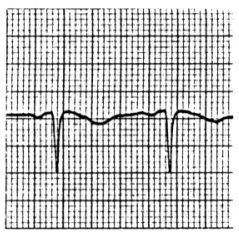

$\mathrm{V}_{4}$
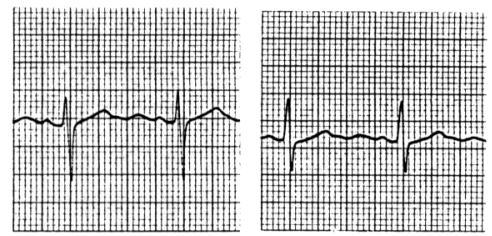

aVL

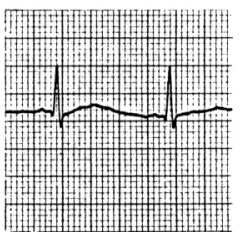

$\mathrm{V}_{5}$

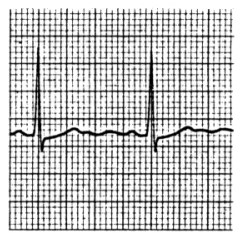

$\mathrm{aVF}$

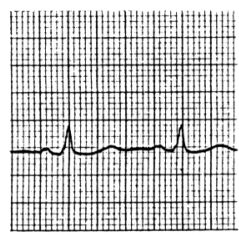

$V_{6}$

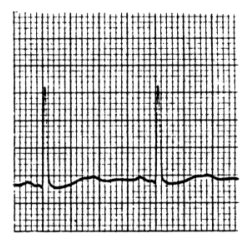

Fig. 1 Electrocardiogram on admission showed T-U waves and prolonged QTU interval.

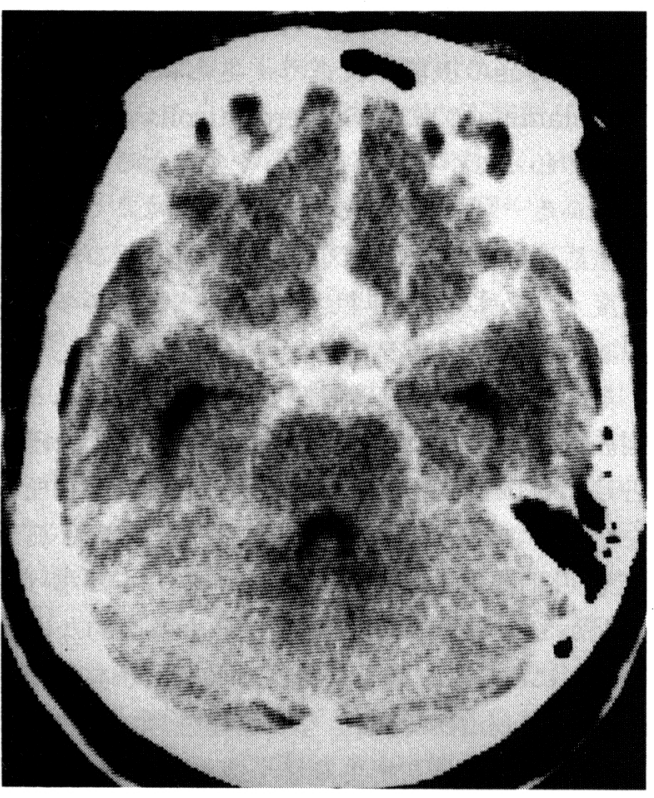

Fig. 2 Computed tomographic scan disclosed diffuse subarachnoid and intraventricular hemorrhage.

頭部 CT ではび漫性のくも膜下出血と脳室内に血液 の逆流がみられた（Fig. 2)。引き続き行った脳血管撮 影で前交通動脈動脈瘤が発見された（Fig. 3).

〔経過〕グリセオール，ステロイドを投与し，脳動

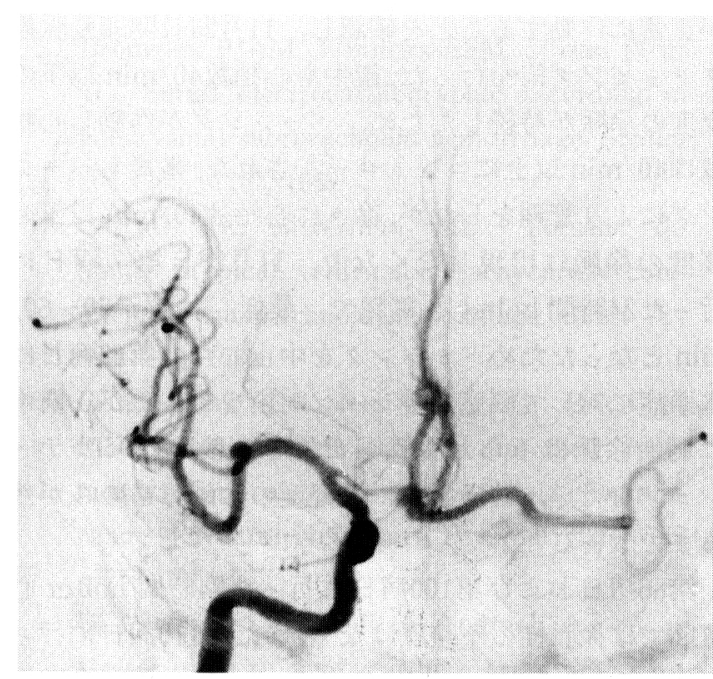

Fig. 3 Right carotid angiogram showed an anterior communicating aneurysm.

脈瘤根治術を予定していたが，11月23日くも膜下出血 発症約 40 時間後より心電図モニターで心拍数 $40 / \mathrm{min}$ 以下の洞性不整脈が出現した (Fig. 4)。神経学的には 入院時と変化はなく，また血液生化学検査でも新たな 異常の出現はなかった。 その後数時間の経過で徐脈が 進行し， 3 秒以上の洞停止扣よび洞性不整脈がみられ るようになり, atropine の静注による効果がないこと 

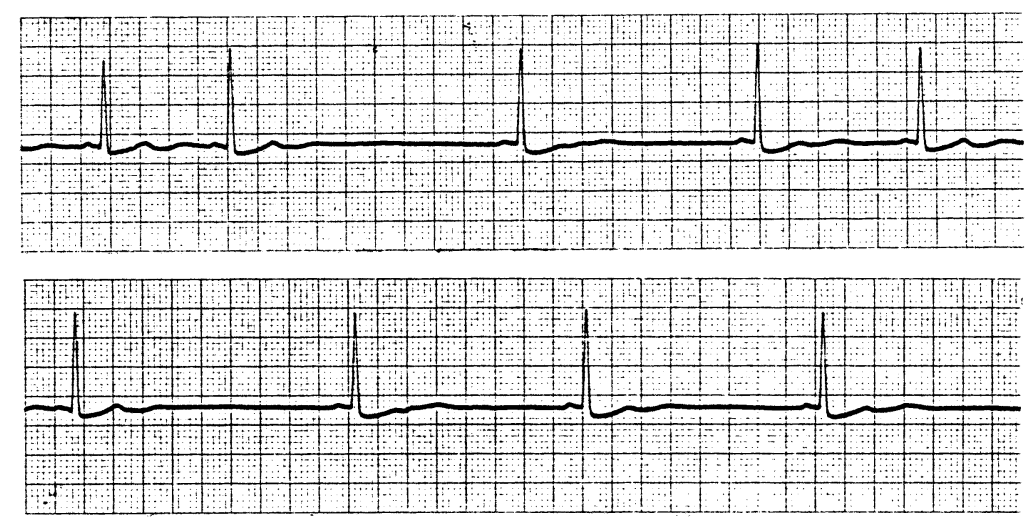

Fig. 4 Sinus arrhythmia and bradycardia under $40 \mathrm{bpm}$ were noted on the electrocardiac monitor 40 hours after the onset of subarachnoid hemorrhage.

から洞不全症候群と診断した。

高度の徐脈による循環不全を予防するために一時 ペーシングの適応と判断し, 右頝静脈より temporary cardiac pacing のカテーテルを右室に挿入し，心拍数 を40/min 以上に保った. Temporary cardiac pacing が正常に作動することを確認し，11月24日開頭動脈瘤 クリッピング術を行った. 術中も心拍数 $40 / \mathrm{min}$ 以下の 高度の徐脈が持続したため, ペーシングが作動し心拍 数は $40 / \mathrm{min}$ 以上にコントロールされた. 術後もペーシ ングにより管理をしたが, 徐々に心拍数 $40 / \mathrm{min}$ 以下の 高度の徐脈は出現しなくなり，11月28日第 7 病日に 行った24時間 holter 心電図で, 最低心拍数が50～60/ $\min$ となったためペーシングを中止した。第28病日に 水頭症に対して脳室腹腔シャント術を行ったが, 術中 に洞性徐脈はみられなかった。その後リハビリテー ションを行い, 神経学的には軽度の知能障害のみが残 るまで改善した。

第86病日および第100病日に行った24時間 holter 心 電図では徐脈性の不整脈はなく, また第110病日に行っ た overdrive suppression テストでは最大洞結節回復 時間の延長はなく, 洞機能の異常を示す所見は認めら れなかった。 またそのほかの電気生理学的機能検査で も，刺激伝導系の機能に異常はみられなかった。これ らの結果より，〈も膜下出血急性期にみられた洞不全 症候群は一過性の中枢性の不整脈と診断した。

\section{考察}

くも膜下出血の急性期には，心電図異常が出現しや すいことが知られて扣り ${ }^{1)}$ 16), 連続的な心電図モ二 タ一による詳細な報告も散見される(1)3)6) 8)11)16). これ
らの報告によると, その発生頻度は50～100\%と極めて 高率であり，その汇ととどはくも膜下出血発症 2 日以 内の急性期に起こり，2 日から 7 日で消失することが 多いとされている(1)3)6)8) 11)14) 16).

不整脈の発生機序として, くも膜下出血による急激 な頭蓋内圧亢進や視床下部の直接障害より交感神経ま たは迷走神経の機能が亢進し,さらに循環血液中の catecholamine の増加, hypercortisolismによる低 $\mathrm{K}$ 血症が加わって不整脈が出現しやすくなるものと考光 られて(る1)3667)1012)14)16). また最近では, くも膜下出 血の重症度や予後と心電図異常の出現および不整脈の 重症度とは必ずしも相関しないという報告が多いが, な执議論のあるところである(13)5) 7)9111)15)16).

心電図異常は波形の異常と不整脈に大別される。心 電図波形の異常としては，一過性の心筋虚血を示す所 見として ST-T の変化, 異常 $\mathrm{Q}$ 波, 心筋の再分極の障 害を示すとされる QTc 間隔の延長, 著明なU 波およ び、T波の平低化・分裂・陰性化・増高などが挙げられ る.なかでも QTc間隔の延長は最も特徵的な所見で 40〜 60\%にみられ，著しい延長は致死的不整脈である torsade de pointes ( $\mathrm{Tdp}$ ) 型の心室性頻拍につながる 恐れがある112)5) 10112)14)15).

つぎに不整脈は, 頻脈性心房粗細動, 多源性頻発性 心室性期外収縮, Tdp な゙の発作性心室頻拍および心 室細動などが malignant arrhythmia として注目され ており, 特に発作性頻拍はくも膜下出血直後の意識消 失拉よび突然死の原因となる場合もあり, くも膜下出 血急性期には厳重な心電図モニターが必要であ る(1) 4)6) 9)13). しかしながら, 臨床的に問題となるよう な不整脈は希であり，一般的には散発性にみられる上 
室性抒よび心室性期外収縮，洞性頻脈抒よび洞性徐脈 などが多(、2)366779916)。

我々の施設で最近 1 年間に経験したくも膜下出血 26 症例のなかで, 入院時の心電図では77\%に異常がみら れた。このなかで主なものは, QTc 間隔の延長が10例 $38.5 \%$, 虚血性 ST-T 変化 3 例, 異常 Q 波 1 例, 著明 な $\mathrm{U}$ 波 2 例, 洞性頻脈 7 例, 洞性徐脈 4 例おょよ゙期外 収縮 4 例であった。

また経過中に心拍数 $40 / \mathrm{min}$ 以下の高度の徐脈を呈 した症例は 2 例で, いずれの症例も入院時には徐脈性 の不整脈はみられなかった。1 例は atropine に反応し たが，提示した症例は atropine の効果はなかった。 こ の症例では検查所見より弁膜疾患や心筋自体の器質的 障害が否定され，末た徐脈は急性期に一過性で消失し ており, その後繰り返し行われた 24 時間 holter 心電図 および overdrive suppression テストなどの電気生理 学的検査の結果より刺激伝導系の機能に異常はみられ ず，くも膜下出血の急性期にともなった中枢性不整脈 と診断した。

このように, くも膜下出血の急性期には徐脈性の不 整脈が多くみられるにも拘らず1336)(8)9916)，あまり関心 が払われていない。これは，徐脈性の不整脈があって も心拍数 $40 / \mathrm{min}$ 以下の高度の徐脈, 3 秒以上の長い洞 停止, 洞性不整脈を伴う洞不全症候群を呈する症例は, くも膜下出血急性期に出現する不整脈の約 $5 \%$ 程6) 比較的少ないためと考学られる(13)816).

くも膜下出血急性期に一過性の洞性徐脈が出現する 機序として，Estanol らは急激な頭蓋内圧六進による 迷走神経の機能六進をあげている8 独で出現する場合と, 経過中に種々の不整脈を合併す るものがあり ${ }^{16)}$, 特に洞性徐脈と洞性頻脈が繰り返し 起こる場合には徐脈頻脈症候群として広義の洞不全症 候群にいれられる。この場合の頻脈直後の洞停止は overdrive suppression 現象によるものと考えられて いるが，頻脈を伴わない例の洞停止，洞性徐脈性不整 脈の原因は, これらの不整脈がくも膜下出血急性期に 一過性で消失することから自律神経機能の調節障害に よるものと思われる8).

いったん高度の徐脈になると心拍出量が低下して脳 循環に悪影響を及ぼすだけではなく，高度の徐脈によ る sinus pause 後にQTUが著明に延長し，このとき R on T の形で VPC を生じ, 致死的不整脈である Tdp に移行することがあるといわれている ${ }^{17)}$.それゆえく 子膜下出血急性期に徐脈性の不整脈がみられた場合に
は, 高度の徐脈に進行しないかどうか心電図モニター による厳重な監視が必要である。

また破裂脳動脈瘤に対して急性期根治手術が一般的 に行われているが, atropine に反応しない高度の徐脈 が出現した場合には，くも膜下出血に伴う洞不全症候 群を念頭に置き，周術期とくに術中の循環管理のため に一時ペーシングの適応を考慮しなければならない。 これにより一定の心拍数を保ち, 徐脈を消失させるこ とで, QTc 延長，心室性期外収縮さらには致死的不整 脈である Tdpを予防することもできる ${ }^{17) .}$

\section{文献}

1) Andreol A, Di Pasquale G, Pinelli G, et al: Subarachnoid hemorrhage: Frequency and severity of cardiac arrhythmias. A survey of 70 cases studied in the acute phase. Stroke $18: 558$ $-564,1987$

2) 天笠雅春, 佐藤 壮, 鈴木倫保ら：くも膜下出血後 の心電図異常 Torsade de pointes. 脳神経外科 $16: 457-462,1988$

3) Brouwers PJAM, Wijdicks EFM, Hasan D, et al: Serial electrocardiographic recording in aneurysmal subrarachnoid hemorrhage. Stroke $20: 1162-1167,1989$

4) Carruth JE, Silverman ME: Torsade de pointe atypical ventricular tachycardia complicating subarachnoid hemorrhage. Chest 78 : 886-888, 1980

5) Cruickshank JM, Neil-Dwyer G, Brice J: Electrocardiographic changes and their prog. nostic significance in subarachnoid haemorrhage. J Neurol Neurosurg Psychiatry $37: 755$ $-759,1974$

6) Di Pasquale G, Pinelli G, Andreoli A, et al: Holter detection of cardiac arrhythmias in intracranial subarachnoid hemorrhage. Am J Cardiol 59: 596-600, 1987

7) Di Pasquale G, Pinelli G, Andreoli A, et al: Torsade de pointes and ventricular flutterfibrillation following spontaneous cerebral subarachnoid hemorrhage. Int J Cardiol 18: 163 $-172,1988$

8) Estanol BV, Dergal EB, Cesarman E, et al: Cardiac arrhythmias associated with subarachnoid hemorrhage: Prospective study. Neurosur- 
gery $5: 675-680,1979$

9) Harries $\mathrm{AD}$ : Subarachnoid haemorrhge and the electrocardiogram-A review. Postgrad medg Med 57 : 294-296, 1981

10) Marion DW, Segal R, Thompson ME : Subarachnoid hemorrhage and heart. Neurosurgery 18: 101-106, 1986

11) Melin J, Fogelholm R: Electrocardiographic findings in subarachnoid hemorrhage. Acta Med Scand $13: 5-8,1983$

12）元持雅男, 半田 肇, 米川泰弘ら：動脈瘤破裂死亡 例の心電図変化一他の自律神経合併症との関連 一。脳神経 $38: 677-684,1986$

13) Parizel G: Life-threatening arrhythmias in subarachnoid hemorrhage. Angiology 24: 17
$-21,1973$

14) Rudehill A, Olsson GL, Sundqvist $K$, et al : ECG abnormality in patients with subarachnoid haemorrhage and intracranial tumours. J Neurol Neurosurg Psychiatry 50:1375-1381, 1987

15）杉田幸二郎, 佐藤 温 : 脳卒中の心電図. 診断と治 療 8:2083-2093, 1988

16) Stober $T$, Anatatt $T h$, Sen $S$, et al: Cardiac arrhythmias in subarachnoid haemorrhage. Acta Neurochir (Wien) $93: 37-44,1988$

17）小松親義, 岡村哲夫：QT延長症候群, pp345 -348 , 杉本恒明, 安田寿一編集, 循環器疾患. 最 新の治療, '90-'91, XI 章, 11 節, 南江堂, 東京, 1990

\section{Abstract \\ Sick sinus syndrome following aneurysmal subarachnoid hemorrhage -A case report-

\author{
Masaaki Yamamoto, M.D. ${ }^{1}$, Tsuyomi Mizoguchi, M.D. ${ }^{1)}$, Kouichi Shinohara, M.D. ${ }^{21}$, \\ Akihiko Sakaue, M.D. ${ }^{2)}$ and Masamichi Tomonaga, M.D. ${ }^{3)}$ \\ 1) Department of Neurosurgery, Hakujuji Hospital \\ 2) Department of Cardiology, Hakujuji Hospital \\ 3) Department of Neurosurgery, School of Medicine, Fukuoka University
}

A 62 years old female patient with a history of hypertenion was referred to our hospital 24 hours after the sudden onset of headache followed by a loss of consciousness. The patient was drowsy with severe nuchal rigidity. A CT scan revealed a diffuse subarachnoid hemorrhage with intraventricular reflux and cerebral angiograms showed an anterior communicating aneurysm. The laboratory findings of the blood were normal. The electrocardiogram showed T-U waves.

About 40 hours after the onset of subarachnoid hemorrhage, severe sinus bradycardia under $40 \mathrm{bpm}$ with sinus arrhythmia and sinus arrest were noted on the monitoring ECG. Since the repeated intravenous infusion of atropine did not succeeded in controlling sinus bradycardia, temporary cardiac pacing was introduced. The following day, the patient was underwent a successful aneurysmal clipping with her heart rate being controlled by cardiac pacing. Since the holter ECG at 4 days after the operation showed a sinus bradycardia of $50-60 \mathrm{bpm}$ but no severe bradycardia and sinus arrest, it was decided to discontinue the cardiac pacing. Repeated holter ECG and myocardial electrophysiological studies performed postoperatively were normal, therefore, a severe sinus bradycardia which occurred during the acute stage of subarachnoid hemorrhage was considered to be a central neurogenic arrhythmia. We therefore conclude that careful ECG monitoring is required in the acute stage of aneurysmal subarachnoid hemorrhage and temporary cardiac pacing is essential in managing sick sinus syndrome. (Jpn. J. Stroke 13: 400-404, 1991) 